\title{
STRATEGY OF DEVELOPMENT TOURISM BASED ON BOT (BUILD, OPERATE, TRANSFER) IN 2018
}

\author{
Murniyati Yanur ${ }^{1}$, Muchammad Zaenuri ${ }^{2}$ \\ ${ }^{1}$ Master of Government Affaurs and Administration, Universitas Muhammadiyah Yogyakarta, Indonesia \\ ${ }^{2}$ Master of Government Affaurs and Administration, Universitas Muhammadiyah Yogyakarta, Indonesia \\ Murniyatiyanur@gmail.com; ${ }^{2}$ titin.p.widodo@gmail.com \\ DOI: https://doi.org/10.18196/igpp.63115
}

Article Info

Article history:

Received 24 Oct 2019

Revised 30 Oct 2019

Accepted 30 Oct 2019
Keywords: Development, Pariwisata, Build Operate Transfer.

\section{ABSTRACT}

Tourism is one of the large foreign exchange earning fields for the country. The tourism ministry's performance target in 2019 is to bring in 20 million foreign tourists and 275 million local tourists with 260 trillion rupiah in foreign exchange. So that tourism is encouraged both at the Provincial, Regency and village level. This was done to meet the performance target of the ministry of tourism and improve the country's economy.One of the Attractions in West Kalimantan Precisely in the city of Pontianak, which is quite interesting to visit and is a cultural preserve, the Equator Monument. This Equator Monument attraction is one of the mainstay promotions of Pontianak City. To develop the equatorial monument in Pontianak City government in collaboration with several stakeholders to realize the development of a more attractive tourist attraction into the Equator Park. This is one of the reasons for research to see the collaboration carried out in the development and management of the Equator Monument.This research is a qualitative research with a case study approach which intends to see the activities carried out in the daily life of the community and also the interaction process in groups or individuals. Data collection in this study uses the method of observation, interviews and also documentation. Thus, any data that has been collected can be selected and described and conclusions can be drawn. The results of the research related to the cooperation in Build Operate Transfer in the development of tourism in the Equatorial Park showed that there was indeed a collaboration with the City Government and Private Parties. But the key stakeholders who are the driving actors in the development of tourism in Khatuistiwa Park are PT. Mitra Bangun Kota.

\section{INTRODUCTION}

West Kalimantan is one of the provinces that have a variety of city attractions, nature, history and culture, and cuisine. Pontianak City is the capital of West Kalimantan province, which has tourist attractions that can be visited. According to Sutarmidji (tribunpontianak, 2017) said that Pontianak as a city of services and trade, not many industries that absorb labor, so it is highly dependent on trade. But according to the city of Pontianak deserve to be a world destination with the uniqueness that exists. Pontianak Free City has ten attractions and tourist attractions to visit. The objects are the equator monument located at Pontianak's Equatorial Street, Kadariyah Palace and Jami 'Mosque in Kampung Dalam Bugis, Alun Kapuas Park on Jalan Rahadi Osman, Aloe vera Center on Jalan Budi Utomo, Batu Layang 
Tomb on Jalan Batulayang, Kalbar Museum on Jalan Ahmad Yani, Malay House, Radang House and Betang House on Jalan Sutan Syahrir.

From the data of the Department of Youth, Sports, and Tourism of the City of Pontianak, the visit of domestic and foreign tourists grows every year. Although in 2015 there was no increase or only recorded 921 thousand international and domestic tourist visits. Lower than the number of visits in 2014, which recorded 957 thousand tourists. From government regulations related to tourism development based on development commitments and other sectors such as the public and public sectors that govern good governance. Theoretically, sector development involving non-state actors in public administration studios known as good governance, the coordination of beneficial cooperation between the public and private sectors under ethical principles (Zaenuri, M., Sumartono., Zauhar., S and Wijaya, AF, 2015).

Therefore the Equator Monument attraction is developing to increase visits. Cultural development in the city of Pontianak not only supports to preserve and develop a culture to achieve certain standards but also to utilize the rich treasures of arts and culture in the economic field that specifically supports tourism. The cultural wealth is the potential of the creative economy that is managed to create jobs and alleviate poverty.

Cooperation between the Regional Government and the private sector is a breakthrough that can be done in order to support regional development. In addition, private and community participation in development planning with good governance or good governance has become a trend or global election as a model in general governance. Good governance governing the administration of governance required a balance of government and participation between government, business (private), and society (civil society) (Muhammad Zea Algabili, Budi Santoso, Hendro Saptono, 2016, p. 2). Collaboration is an alternative to support a change in the form of crossstakeholders (Bryson, J. M., Crosby, B. C., \& Stone, M. M., 2006). To develop the Equator Monument attraction, the Pontianak city government requested the help of several stakeholders so as to facilitate the development of more attractive attractions. In this case, it is a collaboration with a third party (tribunkotapontianak, 2018). Furthermore, proving in (Beritasatu, 2015) that PT. Mitra Bangun Kota got the right to manage the land for 30 years. But in this case, there is still no clarity on who is involved in this collaboration and the involvement of these stakeholders. Unclear information regarding the collaboration carried out by several of these stakeholders. BOT (Build, Operate, Transfer) Therefore, based on the above research, researchers are interested in conducting research under the title "BOT-based tourism development strategies (Build, Operate, Transfer) in 2018 (Case Study: Equator Monument in Pontianak City) ". 


\section{RESEARCH METHOD}

In this case, researchers have chosen to research Pontianak City, West Kalimantan Province. The location of the leading research object is the Equator Monument. And this research was conducted in 2019. The type of research used in this thesis is descriptive and qualitative methods. The data analysis technique in this research is processing data that has been obtained, both data in the form of interviews, documents, archives, or important notes as well as photos and recordings that have been found. The data analysis that will be used in this research is data reduction, data presentation and data verification (Sugiyono, 2012): Data reduction, Data Presentation, and Verification

\section{RESULT AND DISCUSSION}

\section{Tourism Development}

To be able to find out the existence of tourism development in the Equator Monument attractions, the following are indicators of tourism development. In this case, the equator monument attractions keep trying to improve and improve the quality of tourism.

Tourism Development Indicators

\section{Attraction}

The attraction is an attraction of an area or region and even a country that is built on the basis of regional conditions, whether natural or artificial. Attraction attracts tourists to come to a location, and facilities provide tourists' needs while away from where they live, infrastructure and transportation are needed to visit tourist destinations, while hospitality/services show how and how to provide services to tourists.

The attraction that is in an area is also the identity of the region; this is because not all attractions are the same between one area to another. In this case, the tourist attraction in an area can originate from naturally formed geographic elements, and can also occur on the basis of human creativity. For this reason, the following natural and artificial attractions will be presented at the Equator Monument attraction.

\section{Natural Attraction}

The Equator Monument has exciting natural attractions to visit. Kapuas River, which is the longest river in Indonesia that divides the city of Pontianak, has become the main icon of this city. Besides, the existence of the Equator Monument in the city that was founded in 1771 offers a panoramic view of the beauty of Pontianak and 
310 several historic sites in Pontianak. The famous natural attraction at this location is the culmination event. Based on a large Indonesian dictionary, Kulminasi means the highest peak / highest level or the highest point reached by a celestial body in its circulation. In terms of the contextual, culmination or equinox is interpreted as a natural phenomenon when the sun is directly above the equator. This unique natural phenomenon occurs twice in one year, between March 21-23 and September 21-23. This natural event becomes an annual event in the city of Pontianak that attracts both local and foreign tourists. The solar culmination festival is packaged by the Pontianak City Culture and Tourism Office into the Enchanting Kulmunasi Matahari event. At the time of the culmination phenomenon, there is another uniqueness besides the loss of the shadow, the uniqueness is the standing of the eggs placed at the center of the equator. The culmination festival itself even though it has become an annual event, but the number of tourists who come is very volatile and tends to be small. This happens because of several factors, including the time of the event that does not coincide with national holidays and the lack of innovation and promotion carried out by local governments. Of the two factors that are difficult to change is the time of the culmination festival; this is because culmination is a natural phenomenon that occurs at a certain time and cannot be changed according to human will.

\section{Artificial Attraction}

Artificial attractions are made to support natural attractions in certain areas. Some of the artificial tourism objects in the Khatulistiwwa monument are partly made by the community for the needs of the surrounding environment, but the manager of the tourism village sees that there are tourism opportunities if processed with a different appearance.

- Equator Monument

- Culinary

\section{Activities}

In addition to offering the beauty of the equatorial monument as an attraction, Khatulistiwa Park also offers water-guided tours using ships with very attractive tourist destinations, offering panoramic views of the city of Pontianak and several historic sites in the city of Pontianak. The historic sites are started from Kapuas Square, Dwikora Harbor, Equator Monument, Pontianak Sultanate Tomb, Betong Palace, Kadariyah Palace, Jami Mosque, Seng Hie Harbor, Kapuas Bridge, and Banjar Serasan Kampong. Visitors to the Kapuas River Cruise will not only travel or relax but will also receive educational value about the historical standing of the city of Pontianak. Kapuas River Cruise also provides:

प Kapuas river tour package 


\section{Student packages (Study Tour)}

๑ Other special packages (Special Occasion); Corporate/family gathering

This tour is a collaboration of the Kartika hotel with the City Government and the current manager. In addition, there are also ships on the pier that are ready to serve directly if there are tourists and tourists who want to travel along the river.

\section{Amenity}

If you want to visit the Equator Monument attraction, visitors or tourists need not feel anxious about the conditions or facilities available at the attraction. Because the position of this tourist attraction is not far from the urban center. The manager of the tourist attraction will provide free tour guide facilities around the tourist attraction. The Tour Guide will provide information related to the equator monument. In the equator monument attractions also have other facilities that are generally also found in other places, namely, bathrooms (MCK), places of worship, shops souvenir. But at the Equator Monument itself does not yet have a cash withdrawal (ATM) for all types of banks because this facility is Mengistu to urban areas.

\section{BOT (Build, Operate, Transfer) TOURISM}

After knowing the process of developing Equatorial Park through the 3 (three) indicators above, then the collaboration will take place between stakeholders who play a role in developing Equatorial Park.

\section{Development Phase (Build)}

The development and development plan for Equatorial Park, which was built by the investor, is divided into 2 (two) stages. The stages of technical development are as follows

a. The first phase includes plazas, restaurants, monuments, riverside, and mini forests.

b. The second phase consists of a hotel and a water park

According to the manager in the second phase, the hotel to be built has a height of seven floors with a capacity of 100 rooms. PT. Mitra Bangun Kota wants the hotel to have five-star facilities. All locations are in an area of 8 hectares, and it takes about 40 minutes from Pontianak Supadio Airport. The development process (Build) begins with land clearing by PT. Mitra Bangun Kota, supervised by Pontianak City Government and KODAM. All matters relating to the development, including implementation such as presenting planning consultants, executors, and supervisors, are the rights of PT. City Build Partners. While building PT. Mitra Bangun Kota itself 
312 while surveying the surrounding community. Apparently, there are still many indigenous people around the Equator Monument that have never visited. This was felt to be very ironic by the manager. Until the people near themselves are not interested in attending the Equator Monument itself. That makes PT. Mitra Bangun Kota is challenged to improve management and development, not only for profit but wants to improve not from longing Pontianak to have tourist attractions that become the city's identity.

According to the manager, the investment spent is around $\mathrm{Rp} 180$ billion. The disbursement of investment is divided into two phases, in the first stage amounting to Rp 50 billion and the rest in the second phase. The investment issued by his party will return capital in 20 years. This means that the remainder of the land use period can be used to gain profit. Pontianak City Government has given the right to build and manage Equatorial Park starting in 2015. PT. Mitra Bangun Kota is optimistic that the first stage of the Equatorial Monument property project can be completed in 2016, the second phase will be completed in 2018. The construction process of the First Phase is proceeding properly, and in the second stage until now, it has not yet been built. Meaning that in the process, there has been a construction delay of about one year.

\section{Operate Stage}

Cooperation with build operate, and transfer (BOT) is a cooperation that is mutually beneficial. Expected benefits are found in plaza rentals, parking benefits that will last for 30 years. Khatulistiwa Park as an important infrastructure for the economy of the people of North Pontianak. Because some people depend on their economy by trading in the Khatulistwa Park area. The management phase (Operation) runs in 2016, where most traders rent plazas that have been provided. At the management stage, the emphasis is on the plaza rental that has been provided and the benefits derived from parking facilities. For plaza rental costs, 6 million / month per Plaza. According to the interview results, there are still many traders who are in the Plaza feel expensive for the rental fees set by the manager. But inevitably, they must still follow the pattern that has been set by the current management.

When the operation is running, at least, there must be a good marketing strategy from the manager so that tourists and tourists are interested in visiting the Equator Park.

Table 1.1

Perkembangan Kunjungan Wisatawan Di Kota Pontianak

\begin{tabular}{|c|c|c|c|}
\hline Tahun & Nusantara & Mancanegara & Jumlah \\
\hline 2012 & 712098 & 41021 & 753119 \\
\hline
\end{tabular}




\begin{tabular}{|l|l|l|l|}
\hline $\mathbf{2 0 1 3}$ & 788888 & 25592 & 814480 \\
\hline $\mathbf{2 0 1 4}$ & 932070 & 24955 & 957025 \\
\hline $\mathbf{2 0 1 5}$ & 878712 & 42460 & 921172 \\
\hline $\mathbf{2 0 1 6}$ & 939149 & 30468 & 969617 \\
\hline $\mathbf{2 0 1 7}$ & 957059 & 32532 & 989591 \\
\hline
\end{tabular}

Sumber: data primer dari DISPORAPAR, 2019

From the table above, it can be concluded that the development of tourist arrivals after 2015 has increased from year to year. But for the visit of foreign tourists after 2015, there is a decline in visitors every year. But if we look at the total overall development of tourist visits in Pontianak always increases every year. In addition to the above table, we will also see the progress of visitors at the Equator Monument in table 5.2 below:

Table 1.2

Perkembangan Pengunjung Tugu Khatulistiwa

\begin{tabular}{|c|c|c|c|}
\hline Tahun & Nusantara & Mancanegara & Jumlah \\
\hline $\mathbf{2 0 1 2}$ & 74393 & 6325 & 80718 \\
\hline $\mathbf{2 0 1 3}$ & 72939 & 7290 & 80229 \\
\hline $\mathbf{2 0 1 4}$ & 81919 & 7291 & 89210 \\
\hline $\mathbf{2 0 1 5}$ & 77609 & 8659 & 86268 \\
\hline $\mathbf{2 0 1 6}$ & 86088 & 7494 & 93582 \\
\hline $\mathbf{2 0 1 7}$ & 105617 & 9300 & 114917 \\
\hline $\mathbf{2 0 1 8}$ & 111297 & 10057 & 121354 \\
\hline
\end{tabular}

Sumber : data primer dari DISPORAPAR, 2019

Based on the high table, we can conclude after the cooperation carried out since 2015, the development of visitors to the Equator Monument every year is always increasing. To increase the number of visitors every year, there is certainly a way that is done by the manager.

The manager also promoted through cooperation. For the promotion of PT. Mitra Bangun Kota, in collaboration with the community, PKK ladies, the elderly, and communities who want to do gymnastics or aerobics, are always welcome as long as there is permission, and the manager is also open. Every Saturday or Sunday, there is usually also a community of animals, sports, martial arts, and others. In addition, PT. Mitra Bangun Kota also sent personnel to conduct socialization to several schools for study tours for kindergarten, middle school, high school students, and research are welcome. And if there is a school that needs an outdoor training ground, the Equator Monument can be used. The goal is that the children will invite their parents and 
314 family. PT. Mitra Bangun Kota with the city government if there is an event or what can be done at the Equator Monument. Promotion is more carried out to attract people's interest. For special websites, there are already, but according to the manager, there is no specific management.

\section{Transfer Phase}

BOT in the framework of an infrastructure project is nothing but an agreement whereby the project owner (in this case the government) gives his operator or executor the right (private party) to construct public facilities and infrastructure and operate them within a certain period of time, and take advantage of their operation. Then at the end of the contract, the private sector must return the project it manages to the government in accordance with the BOT agreement. This handover is done after the concession period is over, and the investor gives back the management rights, the physical project, and the facilities and infrastructure that support it to the government without the government paying a certain amount of money. The cooperation that has been carried out is calculated from 2015 until now, which has been running for approximately four years. In accordance with the agreement that after 30 years, the agreement expires, and the land returned (transfer) is controlled by the Pontianak City Government to be extended again or managed by the status of the Pontianak City Government. From the process undertaken to date it can be concluded that the transfer process has not yet been carried out.

\section{CONCLUSION}

Based on research conducted by the author, conclusions can be drawn, including the following:

1. That in the construction of the Equatorial Park, the Pontianak City Government has cooperated with PT. Mitra Bangun Kota for 30 years, which has the aim to develop and manage. Pontianak City Government and KODAM have fulfilled their obligations by providing facilities in the form of land during PT. Mitra Bangun Kota carries out its obligations in the form of development (build) and conducts management and development to be of economic value (operation). After the 30-year agreement ends, the land and building are returned to the Pontianak City Government and KODAM.

2. Implementation of the development and management of Equatorial Park is divided into three stages, namely:

a. The build is the construction phase of the Equator Park

b. The operation that is utilizing the results of development

c. Transfer, namely the resubmission of attractions to the Regional Government 
3. The partnership between the regional government and the private sector has a great opportunity for the region to carry out regional development in terms of infrastructure, tourism objects, and various kinds of innovations for regional development in accordance with the potential that exists in each region.

4. The government, as a regulator in the development of tourism, also provides support for the progress of the City of Pontianak. The government is considered to have paid enough attention to the progress of Pontianak City

\section{REFERENCES}

Achmad Nur Yachya, Wilopo, M. Kholid Mawardi. (Oktober 2016). Pengelolaan Kawasan Wisata Sebagai Upaya Peningkatan Ekonomi Masyarakat Berbasis Cbt (Community Based Tourism) (Studi pada Kawasan Wisata Pantai Clungup Kabupaten Malang). Jurnal Administrasi Bisnis (JAB), Vol. 39, No. 2 .

Adisasmita, R. (2010). Manajemen Pemerintah Daerah. Yogyakarta: Graha IImu.

Adisasmita, R. (2010). Pembangunan Kawasan dan Tata Ruang. Yogyakarta: Graha IImu.

Ansell. C \& Gash. A. (2007). collaborative governance in theory and practice. journal of public administration research and theory, 1-29.

Bryson, J. M., Crosby, B. C., \& Stone, M. M. (2006). The design and implementation of Cross-Sector collaborations: Propositions from the literature. Public Administration Review , 44-55.

Dadan Mukhsin, ST., MT. (n.d.). STRATEGI PENGEMBANGAN KAWASAN PARIWISATA GUNUNG GALUNGGUNG (Studi Kasus Kecamatan Sukaratu Kabupaten Tasikmalaya). Jurnal Perencanaan Wilayah Kota .

Daldjoeni, N. (1999). pengantar geografi untuk mahasiswa dan guru sekolah. Bandung.

Deddy Prasetya Maharani. (2014). PENGEMBANGAN POTENSI PARIWISATA Kabupaten Sumenep, Madura, Jawa Timur (Studi Kasus: Pantai Lombang). Jurnal Politik Muda, 412-421.

Devy, H. A. (2017). PENGEMBANGAN OBYEK DAN DAYA TARIK WISATA ALAM SEBAGAI DAERAH TUJUAN WISATA DI KABUPATEN KARANGANYAR (Studi Kasus Obyek Wisata Air Terjun Jumog di Kawasan Wisata Desa Berjo, Kecamatan Ngargoyoso, Kabupaten Karanganyar). Jurnal Sosiologi DILEMA, Vol. 32, No. 1.

Dimas Kurnia Purmada, Wilopo, Luchman Hakim. (2016). PENGELOLAAN DESA WISATA DALAM PERSPEKTIF COMMUNITY BASED TOURISM (Studi Kasus pada Desa Wisata Gubugklakah, Kecamatan Poncokusumo, Kabupaten Malang). Jurnal Administrasi Bisnis (JAB)/Vol. 32 No. 2 .

Faris Zakaria dan Rima Dewi Suprihardjo. (2014). Konsep Pengembangan Kawasan Desa Wisata di Desa Bandungan Kecamatan Pangkong Kabupaten Pamekasan. JURNAL TEKNIK POMITS Vol. 3, No.2 , 2337-3520.

Fitriyah, F. (2016). model public private patnership dalam peningkatan pelayanan sumber daya air bersih di PDAM kabupaten Greasik. Jurnal kebijakan dan manajemen publik, Volume. 4, Nomor 1. 
316 Hidayat, M. (2011). Strategi Perencanaan Dan Pengembangan Objek Wisata (Studi Kasus Pantai Pangandaran Kabupaten Ciamis Jawa Barat). Tourism and Hospitality Essentials (THE) Journal Vol. I, No. 1, 33-44.

Ibnu Surahman, Paramita Prananingtyas, Siti Mahmudah. (2016). Tinjauan tentang kerjasama pembiayaan dengan sistem Build Operate and Transfer (BOT) dalam mengefisiensikan dan megoptimalkan sistem penyediaan air minum (SPAM) (studi kasus padaPDAM tirta kerta Raharja Kabpaten Tangerang). Diponegoro Law Review Volume 5, Nomor 1.

Ikram, M. (2018). Public Private Partnership Dalam Pengembangan Potensi Wisata Di Kabupaten Kuantan Singingi Tahun 2011-2015. JOM, Vol. 5 , No.1 .

Khairul Mahadi, Fitri Indrawati. (2010). Arahan Pengembangan Obyek Wisata Pantai Tanjung Pasir Kabupaten Tangerang . JUrnal Planesatm, Vol.1, No.1 .

Khitam, M. C. (2012). Kerjasama Antara Pemerintah Daerah, Swasta, Dan Masyarakat Dalam Pengembangan Pariwisata. Ekbis .

Made Heny Urmila Dewi, Chafid Fandeli, M.Baiquni. (2013). Pengembangan Desa Wisata Berbasis Pariwisata Masyarakat Lokal Di Desa Wisata Jatiluwuh Tabanan, Bali. KAWISTARA, Volume 3, No.2, 117-226.

Marpaung, H. (2002). Pengetahuan Pariwisata edisi revisi. Bandung: Alfabeta.

Moleong, L. J. (2014). Metodologi Penelitian Kualitatif. Bandung: PT. Remaja Rosdakarya.

Muchtar Luthfi Malik Al Azhar, Imam Hardjanto, Minto Hadi. (n.d.). Kemitraan Antara Pemerintah Dan Swasta Dalam Pelayanan Publik (Studi Pada Stasiun Pengisian Bahan Bakar Nelayan Kelurahan Ujung Batu Kecamatan Kota Jepara Kabupaten Jepara). Jurnal AdministrasiPublik (Jap), Vol. 1, No. 5 , 1048-1057.

Muhammad Zea Algabili, Budi Santoso, Hendro Saptono. (2016). Pelaksanaan perjanjian Build, Operate And Transfer (BOT) dalam pembangunan aset milik pemerintah daerah (studi pada proyek pembangunan dan pengelolaan pasar turi kota Surabaya). Jurnal Diponegoro Law .

Narbuko, Cholid \& Achmadi, Abu. (2015). Metodologo Penelitian: memberikan bekal teoritis pada mahasiswa tentang metodologi penelitian serta diharapkan dapat melaksanakan penelitian dengan langkah-langkah yang benar. Jakarta: Bumi Aksara.

Oktorina, I. (2010). Kajian Tentang Kerja Sama Pembiayaan Dengan Sistem Build Operate And Transfer (Bot) Dalam Revitalisasi Pasar Tradisional (Studi Kasus Pada Pembangunan Sentral Pasar Raya Padang).

Perencanaan Strategis Kepariwisataan Daerah: Konsep dan Aplikasi. e-Gov Publishing.

Primadany, S. R. (2013). Analisis Strategi Pengembangan Pariwisata Daerah (Studi pada Dinas Kebudayaan dan Pariwisata Daerah Kabupaten Nganjuk). Jurnal Administrasi Publik (JAP), 135-143.

Putra, A. S. (2013). Pola Kemitraan Pariwisata Dalam Manajemen Atraksi Desa Wisata Pampang Kota Samarinda. Jurnal Nasional Pariwisata Volume 5, Nomor 3, 189 - 200.

Rinto Z W Abidjulu. (2015). Strategi Pengembangan Pengelolaan Pariwisata Air Terjun Wera Saluopa Di Kabupaten Poso. Jurnal Katalogis Volume 3 Nomor 5 , $1-12$.

Santoso, B. (2008). Aspek Hukum Pembiayaan Proyek Infrastruktur Model BOT (Build Operate and Transfer). Solo: Genta Press.

Sefira Ryalita Primadany, Mardiyono, Riyanto. (2013). Analisis Strategi Pengembangan Pariwisata Daerah (Studi Pada Dinas Kebudayaan Dan 
Pariwisata Daerah Kabupaten Nganjuk). Jurnal Administrasi Publik (Jap) , 135-143.

Sriyanti andayani, M. Ruslin Anwar, Antariksa . (n.d.). Pengembangan kawasan wisata balekambangan kabupaten malang. Jurnal Administrasi Publik (JAP), Vol. 1, No. 5, 1048-1057.

Sulthon Rohmadin. (2016). Strategi Pengembangan Kawasan Wisata Berbasis Pembangunan Berkelanjutan Di Kabupaten Ende Provinsi Nusa Tenggara Timur. Jurnal Politik Pemerintahan, 141-153.

Sunaryono, B. (2013). Kebijakan Pembangunan Destinasi Pariwisata Konsep dan Aplikasinya di Indonesia. Yogyakarta: Gava Media.

Sudaryat. (2008). Legal Officer. Bandung: Oase Media.

Thoha, M. (2003). Perilaku organisasi konsep dasar dan aplikasinya. Jakarta: PT. Raja Grafindo Persada.

Troung, T. (2002). Holiday satisfaction of Australiantravellers in Vietnam: an Application of the HOLSATmodel. Melbourne: Unpublished Masters Dissertation, RMIT University.

Yoeti, O. A. (2008). Perencanaaan dan Pengembangan Pariwisata. Jakarta: Pradaya Pratama.

Zaenuri, M. (2014). Mengelola Pariwisata-Bencana: perluya perubahan paradigma pengelolaan pariwisata Dari Adaptive Governance Menuju Collaborative Governance . Jurnal UNISIA, Vol. XXXVI No.81, 157-168.

Zaenuri, M. (2012). Perencanaan Strategis Kepariwisataan Daerah Konsep dan Aplikasi. Jogjakarta: e-Gov Publishing.

Zaenuri, M., Sumartono., Zauhar, S dan Wijaya, A.F. (2015). The Need of Shared Vision in Tourism Sustainable Development. Journal of Administrative Sciences and Policy Studies, 19-32. 